\title{
81. Chemical Studies on Tomato Ring Mosaic Virus.
}

\author{
I. The Isolation of Crystalline Tomato Ring \\ Mosaic Virus Protein. \\ By Matsunosuke Kitagawa and Satoru Akune. \\ Institute of Agricultural Chemistry, Faculty of Agriculture, \\ Kyushu Imperial University, Fukuoka. \\ (Comm. by U. SuzuKI, M.I.A., Oct. 11, 1941.)
}

We isolated a crystalline protein from tomato ring mosaic-diseased tobacco plants cultivated in our garden, and ascertained that the protein, several times recrystallized, possessed the properties of tomato ring mosaic virus. So far this virus has been never found in crystalline form.

This ring mosaic disease, used for the isolation of crystalline virus, had been found on tobacco plants in our garden by Nakata and Takimoto $^{1)}$ and considered to be similar to the tomato ring mosaic described by Johnson".

\section{Experimental.}

Method of Isolation.-For the isolation of virus protein, we refered to mainly Stanley's modified method. ${ }^{3)}$

$10 \sim 15 \mathrm{~cm}$ high Tobacco plants (Bright Yellow) were inoculated with tomato ring mosaic virus found in our garden. About four weeks later $200 \mathrm{gm}$ of the diseased leaves on fresh weight basis, were taken, and were frozen and ground. The pulp was extracted twice with 150 c.c. of $0.1 \mathrm{M}$ sodium phosphate at $\mathrm{pH} 7.0$. To 445 c.c. of the combined extracts were added $90 \mathrm{gm}$ of ammonium sulphate, and the precipitate was filtered by the addition of $9 \mathrm{gm}$ of silicious earth (Takeda) on a Buchner funnel. The filter cake was dissolved in 70 c.c. of $0.1 \mathrm{M}$ phosphate at $\mathrm{pH} 7.0$ and the filter residue was washed with 30 c.c. of $0.1 \mathrm{M}$ the phosphate. To the dark brown solutions combined, were added $10 \mathrm{gm}$ of ammonium sulphate, and the precipitate, obtained on filtration with $2 \mathrm{gm}$ of silicious earth, was dissolved in 70 c.c. of phosphate at $\mathrm{pH} 7.0$ and the filter residue was washed with 30 c.c. of the phosphate. The brown solution obtained, was once more treated in the same manner as just described. The solution thus prepared was opalescent and light brown in color.

It was adjusted ta $\mathrm{pH} 4.5$ by the addition of 2 c.c. of $5 \mathrm{~N} \mathrm{H}_{2} \mathrm{SO}_{4}$ and filtered with $2 \mathrm{gm}$ of silicious earth. The precipitate was dissolved in 65 c.c. of water adjusted to $\mathrm{pH} 8.0$ by 0.1 per cent. $\mathrm{CaO}$ solution, the filter residue being washed with water and two solutions being combined. The protein in this colorless opalescent solution obtained, was crystallized by the addition of $9 \mathrm{gm}$ of ammonium sulphate, and then 0.45 c.c. of solution of 5 per cent. glacial acetic acid in 0.5 saturated ammonium sulphate for the adjustment of the hydrogen ion concentration to $\mathrm{pH} 4.5$. 
After standing overnight at $5^{\circ}$, the crystallized protein was isolated by centrifugation and was recrystallized several times by the same procedure for the last crystallization. The yield of crystalline virus after three times recrystallization from $200 \mathrm{gm}$ of the fresh leaves amounted to $0.01 \mathrm{gm}$. The crystalline virus was isolated also from other tobacco plants, namely, Little Duch and Kagoshima Maruba, infected with

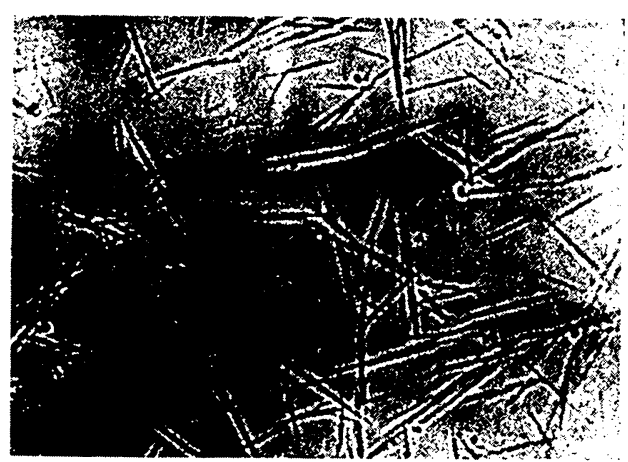

Fig. 1. 5-times recrystallized tomato ring mosaic virus protein from tobacco plants. $\times 1,000$ the same disease.

General properties and infectivity of crystalline protein.-The crystals are needles about $0.02 \mathrm{~mm}$ long. Its solution gives a positive test with biuret, xanthoproteic, glyoxylic acid, and Millon's reagénts. The Molisch test is similary negative as in the case of aucuba mosaic virus $^{4)}$. The material is precipitated by usual protein-precipitant.

The infectivity of the protein was tested by rubbing 0.1 per cent. solution of three-times recrystallized protein over the leaves of several

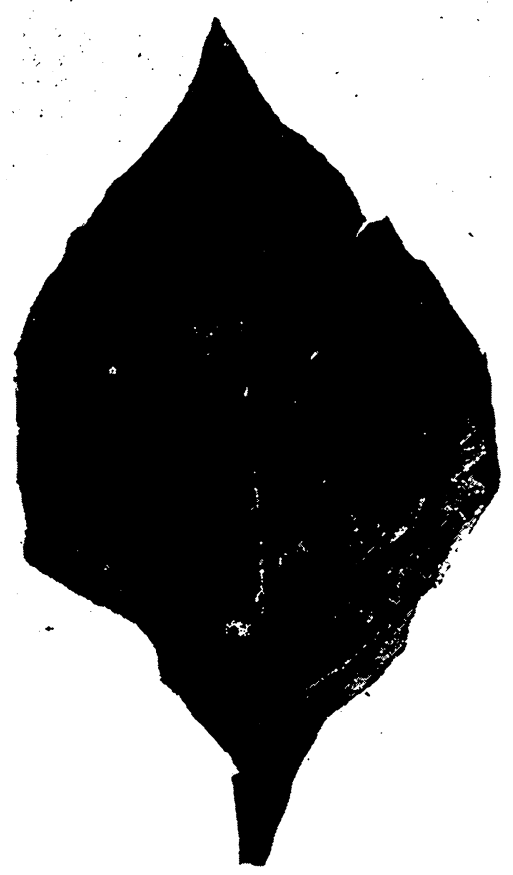

Fig. 2. The tomato ring mosaic virus on Tubocapsicum anomalum.

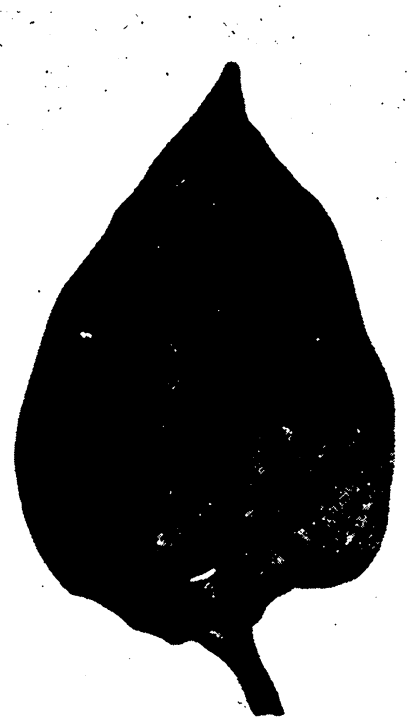

Fig. 3. The tobacco mosaic virus on Tubocapsicum anomalum. 
[Vol. 17,
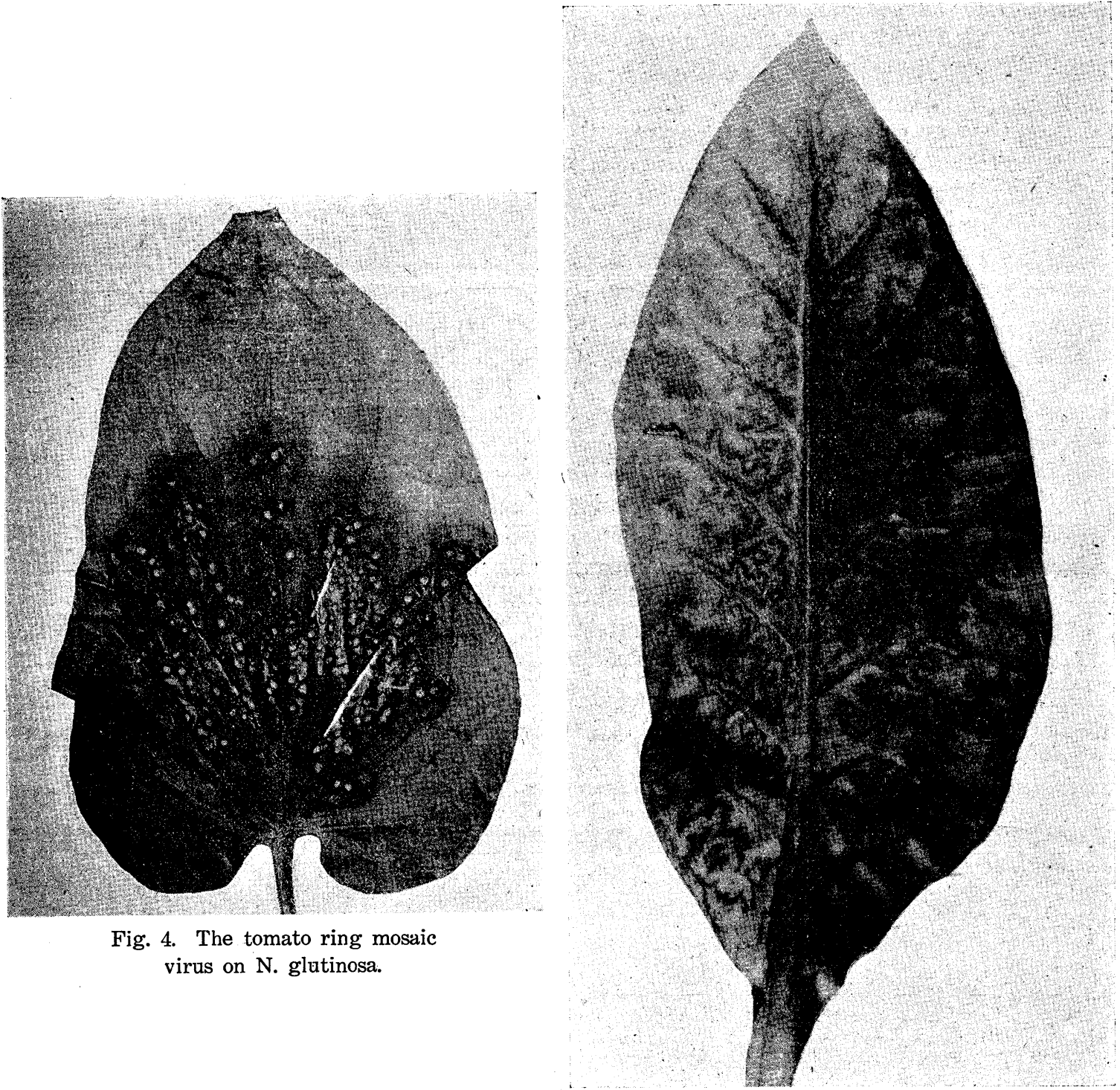

Fig. 5. The tomato ring mosaic virus on N. tabacum (Bright Yellow).

plants, namely, Nicotiana tabacum (White Burley, Bright Yellow and Little Duch), Nicotiana glutinosa, Nicotiana repanda and Tubocapsicum anomalum Makino. In every case the typical symptom of tomato ring mosaic virus disease appeared as shown in the Fig. 4. 5. 6.

The limit of dilution, at which $\mathrm{N}$. glutinosa and N. repanda were infected with the three-recrystallized protein, was $1: 10^{7}$, and in the case of N. tabacum (Little Duch) it was $1: 10^{8}$.

The infectivity of tomato ring mosaic virus protein was compared with that of tobacco mosaic virus protein by the whole-leaf method." Each protein used for the inoculation, was recrystallized five times. 
No. 8.]

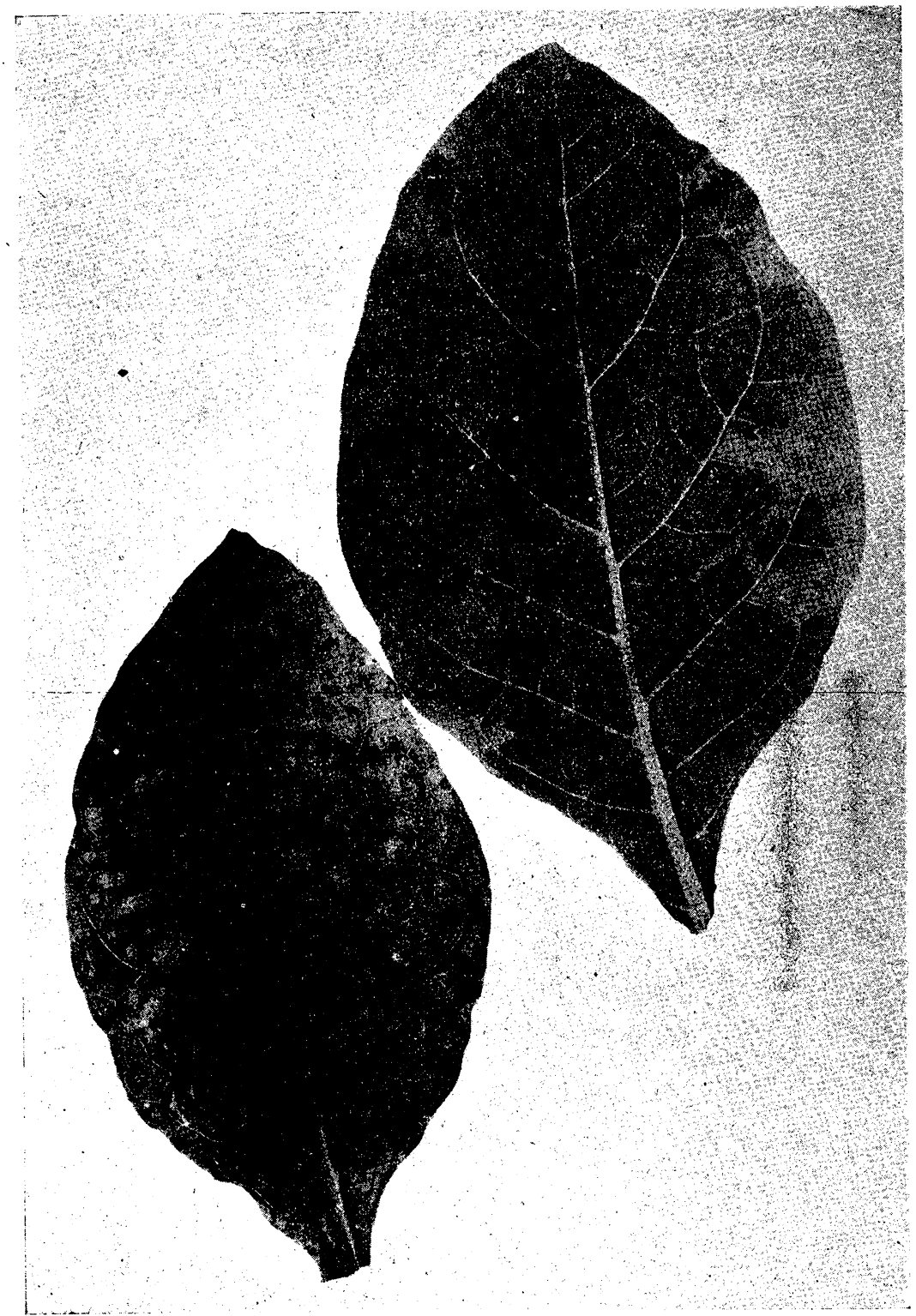

Fig. 6. The tobacco mosaic virus on N. tabacum (Bright Yellow).

The results obtained are given in the following table.

\begin{tabular}{l|c|cccccc}
\hline \multirow{2}{*}{$\begin{array}{c}\text { mosaic } \\
\text { virus } \\
\text { protein }\end{array}$} & $\begin{array}{c}\text { test } \\
\text { plant }\end{array}$ & $1: 10^{4}$ & $1: 10^{5}$ & $1: 10^{6}$ & $1: 10^{7}$ & $1: 10^{8}$ & $1: 10^{9}$ \\
\cline { 2 - 8 } & N. glutinosa & 21.8 & 6.0 & 1.6 & 1.0 & 0.2 & 0 \\
\hline ring & N. glutinosa & 42.0 & 6.0 & 2.6 & 1.2 & 0.4 & 0 \\
\hline tobacco & N. gluting &
\end{tabular}

The crystalline ring mosaic virus protein was as $100 \sim 1,000$ times active as the original juice from the diseased leaves. 
The Studies were done in co-operation with Mr. H. Yoshii, the chief of phytopathological laboratory, and Mr. S. Takimoto. Thanks are due to the Department of Education for a Scientific Research Encouragement Grant.

\section{Literatures.}

1) K. Nakata, S. Takimoto: Agriculture and Horticulture, 16, 401 (1941).

2) E. M. Johnson: Kentucky Agric. Exp. Sta. Bull., 306, 297, (1930).

K. M. Smith: Tent-book of plant virus diseases (London), 293 (1937).

3) W. M. Stanley: J. Biol. Chem., 115, 673, (1936).

4) W. M. Stanley: J. Biol. Chem., 117, 325, (1937).

5) W. M. Stanley: Phytopathology, 24, 1055 (1934). 